Cumhuriyet Üniversitesi Fen Fakültesi Fen Bilimleri Dergisi (CFD), Cilt 38, No. 2 (2017) ISSN: $1300-1949$
Cumhuriyet University Faculty of Science

Science Journal (CSJ), Vol. 38, No. 2 (2017) ISSN: 1300-1949

http://dx.doi.org/10.17776/cumuscij.302489

\title{
Determination of Trace Amounts of Total Fe as Fe (II) in Environmental Samples by Catalytic Kinetic Spectrophotometry
}

\author{
Nuket KARTAL TEMEL ${ }^{1 *}$, Ramazan GURKAN ${ }^{1}$ \\ ${ }^{1}$ University of Cumhuriyet, Faculty of Sciences, Department of Chemistry, TR-58140, Sivas, Turkey
}

Received: 31.03.2017; Accepted: 17.04.2017

\begin{abstract}
The method is based on the selective catalytic effect of iron (II) ions in the presence of 1,10 phenanthroline as an activator, on the oxidation of Coomassie Brillant Blue $2 \mathrm{R}$ by bromate. The catalytic reaction was monitored spectrophotometrically at $520 \mathrm{~nm}$ by fixed time approach of $3 \mathrm{~min}$. The optimization of the operating conditions are investigated. Obtained optimum conditions: $1.5 \mathrm{~mL}$ of Coomassie Brillant Blue 2R $\left(1.0 \times 10^{-4} \mathrm{~mol} \mathrm{~L}^{-1}\right), 0.6 \mathrm{~mL}$ of bromate $\left(0.01 \mathrm{~mol} \mathrm{~L}^{-1}\right), 1.5 \mathrm{~mL}$ of 1,10 -phenanthroline $\left(1.0 \times 10^{-3} \mathrm{~mol} \mathrm{~L}^{-1}\right)$, reaction temperature $25^{\circ} \mathrm{C}$ and time $3 \mathrm{~min}$ in $\mathrm{pH} 2.0$ at $520 \mathrm{~nm}$. The proposed method allows quantitatively determination of iron (II) in the range of $0.05-5 \mathrm{mg} \mathrm{L}^{-1}$ with a selectivity and quantification limit of 0.0141 and $0.047 \mathrm{mg} \mathrm{L}^{-1}$. The relative standard deviations for five replicate determinations of 0.2 and $3 \mathrm{mg} \mathrm{L}^{-1}$ iron (II) are $3.8 \%$ and $2.3 \%$, respectively. The method was applied to determination of total iron in some environmental surface waters such as lake, river and well water including pharmaceutical samples used in the treatment of iron deficiency (such as ferrosolanol and maltose) after pre-reduction of iron (III) to iron (II) with sulfite at $40{ }^{\circ} \mathrm{C}$ at $\mathrm{pH} 4.0$, and quantitative percentages of retinas ranging from $98.7-102.7 \%$ were obtained by standard attachment-based analysis after wet acid dissolution for possible matrix effect.
\end{abstract}

Keywords: Iron (II), Coomassie Brillant Blue 2R, 1,10-Phenanthroline, Bromate, Kinetic method

\section{Katalitik Kinetik Spektrofotometri ile Çevresel Örneklerde Eser Miktarlardaki Toplam Fe'nin Fe(II) Olarak Belirlenmesi}

\begin{abstract}
Özet. Yöntem, Coomassie Brillant Blue 2R'nin bromat ile oksidasyonuna, aktivatör olarak 1,10-fenantrolin varlığında demir (II) iyonlarının seçici katalitik etkisine dayanır. Katalitik tepkime yaklaşık 3 dakikalık sabitlenmiş-zaman yaklaşımı ile $520 \mathrm{~nm}$ 'de spektrofotometrik olarak izlenmiştir. Uygulama koşullarının optimizasyonu araştırılmıştır. Elde edilen optimalkoşullar: $1.5 \mathrm{~mL}$ Coomassie Brillant Blue $2 \mathrm{R}\left(1.0 \times 10^{-4} \mathrm{~mol} \mathrm{~L}\right.$ $\left.{ }^{1}\right), 0.6 \mathrm{~mL}$ bromat $\left(0.01 \mathrm{~mol} \mathrm{~L}^{-1}\right), 1.5 \mathrm{~mL}$ 1,10-fenantrolin $\left(1.0 \times 10^{-3} \mathrm{~mol} \mathrm{~L}^{-1}\right), 25^{\circ} \mathrm{C}$ tepkime sicaklığ and $\mathrm{pH} 2.0$ de, $520 \mathrm{~nm}$ 'de 3 dakikalık tepkime zamanıdır. Önerilen yöntem, $0.0141 \mathrm{mg} \mathrm{L}^{-1}$ ve $0.047 \mathrm{mg} \mathrm{L}^{-1}$ lik seçme ve nicelleştirme sınırı ile $0.05-5 \mathrm{mg} \mathrm{L}^{-1}$ aralığında demir (II)'nin tayinine izin verir. 0.2 ve $3 \mathrm{mg} \mathrm{L}^{-1}$ demir (II)'nin beş tekrarlı analizi için elde edilen bağıl standart sapma değerleri sırasıyla $\% 3.8$ ve $\% 2.3$ tür. Yöntem, $\mathrm{pH} 4.0$ ve 40 ${ }^{\circ} \mathrm{C}$ 'de sülfit ile demir (III)'ün demir (II)'ye ön indirgenmesi sonrası demir eksikliği tedavisinde kullanılan farmasötik örnekler (ferrosolanol ve maltoz gibi) ve göl, nehir ve kuyu suyu gibi bazı çevresel yüzey sularında toplam demir tayininde uygulanmış, olası örnek matriks etkisi için yaş asitle çözme sonrası standart eklemeye dayanan analizle \%98.7-102.7 aralığında değişen kantitatif gerikazanımlar elde edilmiştir.
\end{abstract}

\footnotetext{
* Corresponding author. Email address: nkartal@ cumhuriyet.edu.tr
} 


\section{INTRODUCTION}

Iron is the most abundant elements on Earth, is essential as it maintains good both plants and animals health [1]. The adult human body contains about $4 \mathrm{~g}$ of iron, of which about $3 \mathrm{~g}$ are in the form of hemoglobin and this level is maintained by absorbing $1 \mathrm{mg}$ of iron per day [2]. Evidence has been presented that at low levels iron is an essential element in the diet, whereas at higher concentrations it is toxic [3]. Iron (II) the preferred nutrient for phytoplankton [4]. Besides, iron (II) is important in the transport and storage of oxygen in animals through the agency of hemoglobine, myoglobine and ironporphyrine enzymes $[5,6]$. The main source of iron in natural waters is from the weathering and leaching of rocks and soils [7]. Also, metallic iron and its compounds are used in various industrial processes and may enter natural waters through the discharge of wastes. Thus, iron ion controls the mobility, bioavailability and toxicity of other trace metals in the natural water system [8].

Development of the determination methods for iron in such samples as foodstuffs is important. There are a number of sensitive analytical methods for a highly sensitive method for quantitative analysis of iron speciation in environmental and biomedical studies [9]. These methods include spectrophotometry [10-13], flourimetry [14], flow-injection analysis [15-17], voltammetry [18], chemiluminescence [19], capillary electrophoresis [20], atomic emission and atomic absorption spectrometry [21, 22], and chromatography [23]. Although some of these methods are highly sensitive, they have disadvantages such as the necessity for expensive and sophisticated instrumentation and can only be used to determine iron (III) and/or total iron content.

In the present work, a kinetic procedure proposed for monitoring and determination of iron (II) in presence of 1,10-phenantroline as activator using its catalytic effect on the oxidation of triphenyl methane group dye, Coomassie brilliant blue $2 \mathrm{R}$ at $\mathrm{pH} 2.0$ by potassium bromate at $25^{\circ} \mathrm{C}$. The reaction was monitored spectrophotometrically at wavelength of maximum absorbance of the dye at $520 \mathrm{~nm}$ in which the absorbance change between the catalyzed- and uncatalyzed-reactions were measured with fixed time approach of $3 \mathrm{~min}$. The proposed method shows a low detection limit and a wide linear range. Advantages of the proposed method are sensitive, accurate, fast, simple and cheap.

\section{MATERIALS and METHODS}

\subsection{Instrumentation}

All absorption measurements at $520 \mathrm{~nm}$ were performed using on a double-beam UV-Visible Spectrophotometer (Shimadzu UV-1800 PC, Kyoto, Japan), equipped with the 1.0-cm quartz cells. The $\mathrm{pH}$ measurements were made using a pH-2005 digital $\mathrm{pH}$ meter equipped with a glass-calomel electrode (pH-2005, JP Selecta, Barcelona, Spain).

\subsection{Reagents and solutions}

Analytical reagent grade chemicals and twice distilled water were used for preparation of the solutions. Stock solution of iron (II) (Fe (II)) (1000 $\left.\mathrm{mg} \mathrm{L}^{-1}\right)$ was prepared by dissolving the appropriate amount of solid $\mathrm{FeSO}_{4} \times 7 \mathrm{H}_{2} \mathrm{O}$ (Sigma-Aldrich) in water. All stock standard solutions were stored in polyethylene bottles in a refrigerator at $4{ }^{\circ} \mathrm{C}$. The working standard solutions were prepared daily by stepwise dilution of the stock solution. A $1.0 \times 10^{-4} \mathrm{~mol} \mathrm{~L}^{-1}$ of Coomassie Brillant Blue $\left(\mathrm{CBB}^{+}\right)$solution was prepared daily by dissolving with water. A $1.0 \times 10^{-3} \mathrm{M}$ of 1,10-phenanthroline (1,10-Phen) solution was prepared fresh daily by dissolving a suitable amount of solid reagent (Sigma-Aldrich) in water. The bromate $\left(\mathrm{BrO}_{3}{ }^{-}\right)$solution of $0.01 \mathrm{~mol} \mathrm{~L}^{-1}$ was prepared by dissolving suitable amount of $\mathrm{KBrO}_{3}$ in $100 \mathrm{~mL}$ of 


\section{KARTAL TEMEL, GURKAN}

water. The formate buffer solutions at $\mathrm{pHs}$ ranging from 1.0 to 4.0 were prepared by mixing $\mathrm{HCOOH}$ and $\mathrm{HCOONa}$ and adjusting to a suitable $\mathrm{pH}$ value by a $\mathrm{pH}$ meter. Before starting the experiment, all the containers such as vessels, glassware, pipettes and PTFE bottles were washed first with $10 \%(\mathrm{w} / \mathrm{v})$ $\mathrm{HNO}_{3}$ solution, and then with diluted $\mathrm{HCl}$ solution $\left(0.1 \mathrm{~mol} \mathrm{~L}^{-1}\right)$, finally they were rinsed with water.

\subsection{General kinetic procedure}

The reagent solutions and water were kept at $25^{\circ} \mathrm{C}$ in the thermostatic water bath for fixed-time of 3 min. An appropriate volume of sample or standard solutions in range $0.05-5 \mathrm{mg} \mathrm{L}^{-1} \mathrm{Fe}$ (II) were added to a $10 \mathrm{~mL}$ volumetric flask, and then sequentially $1.5 \mathrm{~mL}$ of $\mathrm{CBB}^{+}\left(1.0 \times 10^{-4} \mathrm{~mol} \mathrm{~L}^{-1}\right), 1.5 \mathrm{~mL}$ of $1,10-$ Phen $\left(1.0 \times 10^{-3} \mathrm{~mol} \mathrm{~L}^{-1}\right)$ and $0.6 \mathrm{~mL}$ of sodium bromate $\left(0.01 \mathrm{~mol} \mathrm{~L}^{-1}\right)$ solutions and diluted with water to $10 \mathrm{~mL}$. The absorbance change at $520 \mathrm{~nm}$ was measured at 30 and $180 \mathrm{~s}$ from the initiation of the catalyzed-reaction $\left(\Delta \mathrm{A}_{s}\right)$. A blank solution (without iron) was prepared and measured in a similar way $\left(\triangle \mathrm{A}_{\mathrm{b}}\right)$. The difference between absorbance changes for the catalyzed- and uncatalyzed-reactions $(\Delta \mathrm{A}=\Delta \mathrm{As}-\Delta \mathrm{Ab})$ was adopted as analytical signal.

\subsection{Sample collection, preparation of sample to analysis}

Water samples were taken from a local well near Cumhuriyet University in Sivas, Turkey. One milliliter of $1 \mathrm{M} \mathrm{HCl}$ was added per $10 \mathrm{~mL}$ sample to prevent hydrolysis of iron. The samples were stored in polyethylene containers, and then kept under refrigeration at $4{ }^{\circ} \mathrm{C}$. The samples were filtrated before injection with a $0.45-\mathrm{mm}$ membrane filter before kinetic analysis.

\section{DISCUSSION and RESULTS}

\subsection{Effect of pH and format buffer volume}

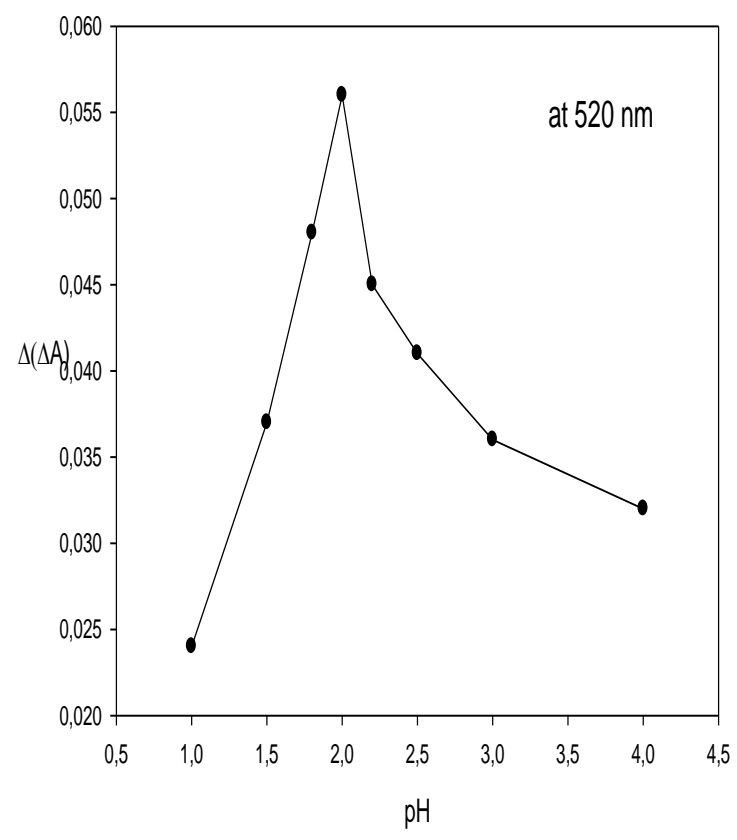

(a)

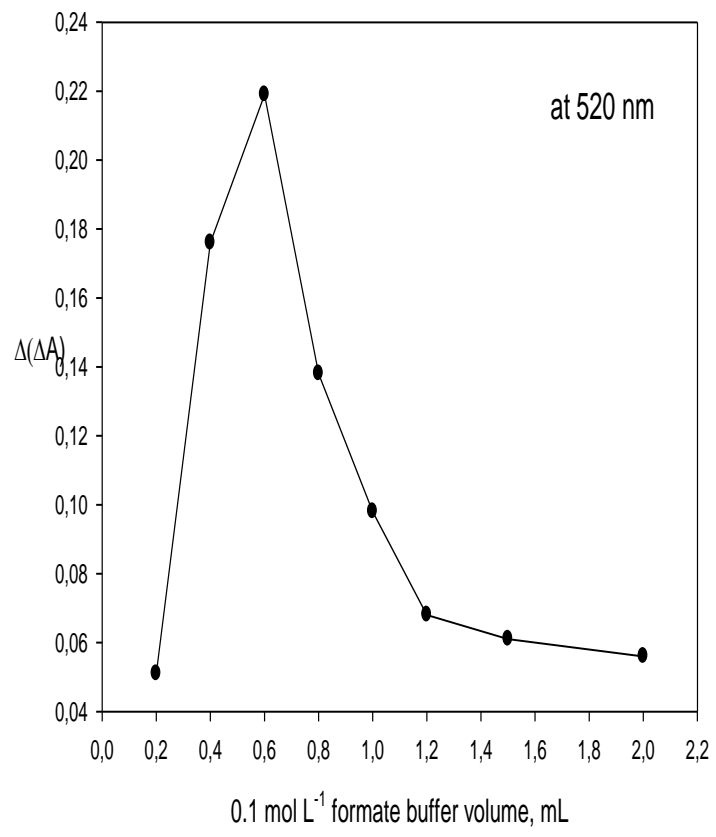

(b)

Figure 1 The effect of (a) $\mathrm{pH}$ and (b) formate buffer volume of $0.1 \mathrm{~mol} \mathrm{~L}^{-1}$ on analytical signal. 
The colour of the dye depends on the acidity of the solution. At a pH of less than 0 the dye has a red colour with an absorption maximum at a wavelength of $470 \mathrm{~nm}$. At a pH of around 1 the dye is green with an absorption maximum at $620 \mathrm{~nm}$ and above $\mathrm{pH} 2$ the dye is bright blue with a maximum at 595 $\mathrm{nm}$. At $\mathrm{pH} 7$ the dye has an extinction coefficient of $43,000 \mathrm{M}^{-1} \mathrm{~cm}^{-1}$ [24]. The $\mathrm{CBB}^{+}$have two sulfonic acid groups that have extremely low pKa's and will normally be negatively charged, thus at a $\mathrm{pH}$ of around zero the dye will be a cation with an overall charge of +1 [24]. The $\mathrm{pH}$ of the solution is kept acidic throughout the experiment to prevent Fe (II) oxidation. In this study, the effect of $\mathrm{pH}$ on the oxidation reaction was investigated in the $\mathrm{pH}$ values ranging from 1.0 to 4.0 spectrophotometrically for catalytic measurement of $0.1 \mathrm{mg} \mathrm{L}^{-1} \mathrm{Fe}$ at $520 \mathrm{~nm}$, as can be seen in Fig. 1(a). From the results obtained, it is clear that the absorbance change linearly increases with increasing $\mathrm{pH}$ in the range of 1.0-2.0, and then gradually decreased due to increase in blank signal. Therefore, the best analytical signal was obtained at $\mathrm{pH} 2.0$ for further studies.

In addition, the effect of buffer volume at $\mathrm{pH} 2.0$ was investigated in the range of $0.2-2.0 \mathrm{~mL}$ at fixed formate concentration of $0.1 \mathrm{~mol} \mathrm{~L}^{-1}$ in Fig. 1(b), and a buffer volume of $0.6 \mathrm{~mL}$ was chosen as optimal value due to give maximum analytical signal.

\subsection{Effect of activator volume}

The iron complexes of 1,10-phenanthroline (1,10-Phen), pyridine (pyr) and 2,2'-bipyridyl (2,2'-bipyr) are widely used as selective metal binding reagents as promoters and/or activators and model compounds of biologically active substances, due to give stable metal complexes [25-29]. The spectrophotometric measurement of a red-orange complex that forms between Fe (II) and 1,10-phen, is practical, highly sensitive and selective in terms of iron speciation [30].

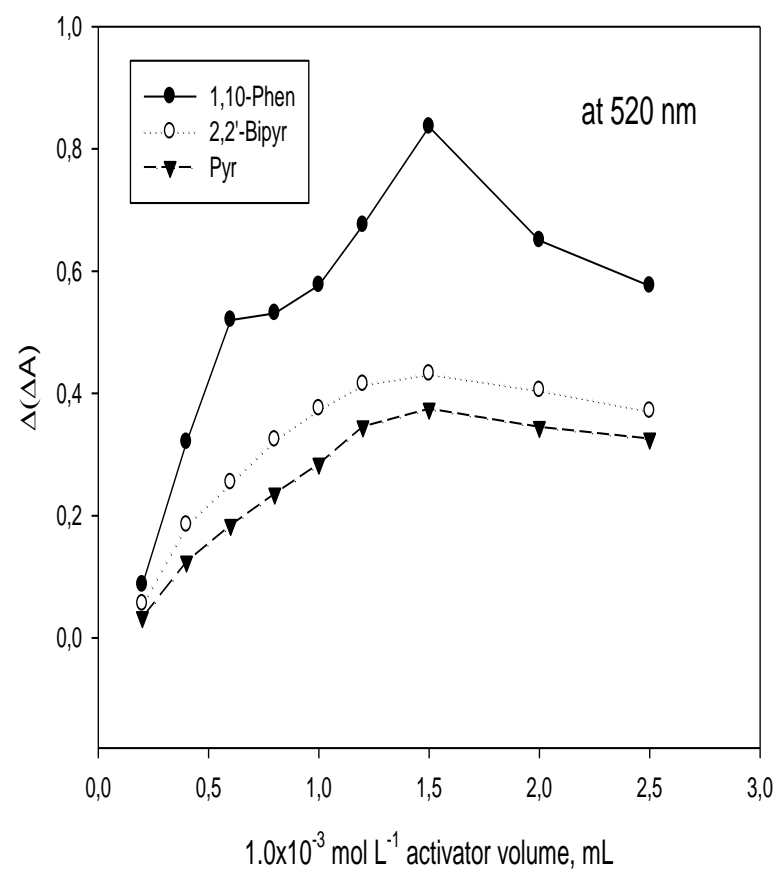

Figure 2. The effect of activator volumes of $1.0 \times 10^{-3} \mathrm{~mol} \mathrm{~L}^{-1}$ on analytical signal. 


\section{KARTAL TEMEL, GURKAN}

The effect of $1.0 \times 10^{-3} \mathrm{~mol} \mathrm{~L}^{-1}$ activator amounts for analytical signal of iron (II) at $0.1 \mathrm{mg} \mathrm{L}^{-1}$ were examined in range of $0.25-2.5 \mathrm{~mL}$ at $25^{\circ} \mathrm{C}$ in Fig. 2. The optimum volume of standard $1.0 \times 10^{-3} \mathrm{~mol} \mathrm{~L}^{-}$ ${ }^{1}$ activator solutions was found to be $1.5 \mathrm{~mL}$ with a significant sensitivity difference.

\subsection{Effect of Bromate volume}

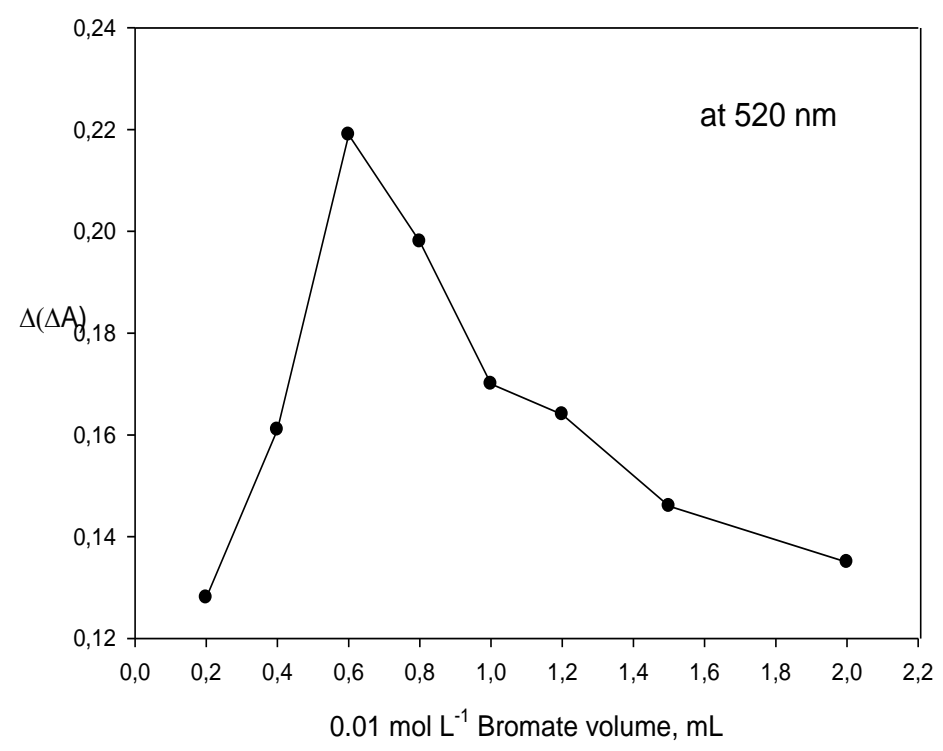

Figure 3. The effect of bromate volume of $0.01 \mathrm{~mol} \mathrm{~L}^{-1}$ on analytical signal.

Dependence of the method sensitivity on the bromate volume at $0.01 \mathrm{~mol} \mathrm{~L}^{-1}$ was investigated in the range of $0.2-2.0 \mathrm{~mL}$ at $20^{\circ} \mathrm{C}$. Fig. 3 shows that the reaction rate increases with bromate volume and that analytical signal $(\Delta \mathrm{A})$ reaches a maximum value at $0.6 \mathrm{~mL}$, whereas the reaction rate gradually decreases with greater bromate volumes than $0.6 \mathrm{~mL}$. The increase in both $\Delta \mathrm{A}_{\mathrm{s}}$ and $\Delta \mathrm{A}_{\mathrm{b}}$ is due to this fact that with increase in bromate concentration, the oxidation ability of bromate increases. According to the results, the bromate volume of $0.6 \mathrm{~mL}$ was chosen as the best bromate volume for further studies.

\subsection{Effect of the indicator dye volume}

The effect of the indicator dye volume, $\mathrm{CBB}^{+}$on the oxidation reaction was investigated in the range of $0.2-2.5 \mathrm{~mL}$ at $1.0 \times 10^{-4} \mathrm{~mol} \mathrm{~L}^{-1}$ was performed under the optimum conditions. According to the results obtained in Fig. 4, the analytical signal, $(\triangle \mathrm{A})$ increase with increase in the $\mathrm{CBB}^{+}$volume, and sensitivity increases up to a volume of $1.5 \mathrm{~mL}$, and then it remains constant. Therefore, $\mathrm{CBB}^{+}$volume of $0.6 \mathrm{~mL}$ was selected as optimal for further studies. 


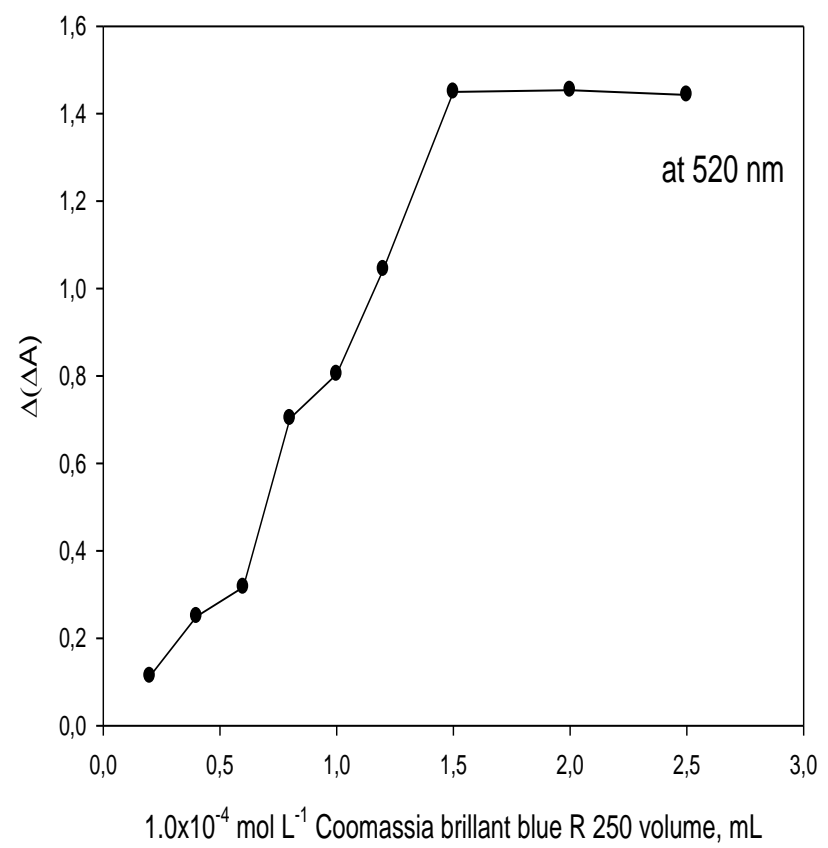

Figure 4. The effect of indicator dye volume, $\mathrm{CBC}^{+}$at $1.0 \times 10^{-4} \mathrm{~mol} \mathrm{~L}^{-1}$ on analytical signal

\subsection{Analytical figures of merit}

Under the optimized reagent conditions, as can be seen in Table 1, sequentially the limits of detection and quantification of the method (LOD: $3 \mathrm{~s}_{\text {blank }} / \mathrm{m}$ and LOQ: $10 \mathrm{~s}_{\text {blank }} / \mathrm{m}$, in which the $\mathrm{s}_{\text {blank }}$ and $\mathrm{m}$ respectively are the standard deviation of ten replicate measurements of sample blank and slope of the calibration curve) of the method for $\mathrm{Fe}$ (II) were 14.1 and $47.0 \mu \mathrm{g} \mathrm{L}^{-1}$, the recovery rates were in range of 98.7-102.7\% with a relative standard deviations of 3.8 and $2.3 \%\left(0.2\right.$ and $3 \mathrm{mg} \mathrm{L}^{-1}$, n: 5), the linear working range was $0.05-1.0$ and $0.25-5.0 \mu \mathrm{g} \mathrm{mL}^{-1}$ with a changing calibration sensitivity. The other analytical features are represented in Table 1.

$$
\begin{aligned}
& \Delta \mathrm{A}_{1}: 0.2971 \mathrm{C}_{\mathrm{Fe}(\mathrm{II})}\left(\mu \mathrm{g} \mathrm{mL} \mathrm{m}^{-1}\right)+0.0285, \mathrm{R}^{2}: 0.9932 \\
& \Delta \mathrm{A}_{2}: 0.1370 \mathrm{C}_{\mathrm{Fe}(\mathrm{II})}\left(\mu \mathrm{gL}^{-1}\right)+0.0021, \mathrm{R}^{2}: 0.9975
\end{aligned}
$$

\begin{tabular}{|c|c|}
\hline Analytical parameters & Analytical sample, $\mathrm{Fe}$ (II) \\
\hline Regression equation (for $\mathrm{N}: 5$ ) & $\begin{array}{l}\Delta \mathrm{A}_{1}: 0.2971 \mathrm{C}_{\mathrm{Fe}(\mathrm{II})}\left(\mu \mathrm{g} \mathrm{mL} \mathrm{m}^{-1}\right)+0.0285, \mathrm{R}^{2}: \\
0.9932 \\
\Delta \mathrm{A}_{2}: 0.1370 \mathrm{C}_{\mathrm{Fe}(\mathrm{II})}\left(\mu \mathrm{g} \mathrm{mL}^{-1}\right)+0.0021, \mathrm{R}^{2}: \\
0.9975\end{array}$ \\
\hline Linear range, $\mu \mathrm{g} \mathrm{mL}^{-1}$ & $0.05-1.0$ ve $0.25-5.0$ \\
\hline${ }^{a}$ Characteristic concentration of the device, $\mathrm{nM}$ & 60.3 \\
\hline Limit of detection, LOD $\left(\mathrm{N}: 12,3 \mathrm{~S}_{\mathrm{b}} / \mathrm{m}\right), \mu \mathrm{g} \mathrm{L}^{-1}$ & 14.1 \\
\hline Limit of quantification, LOQ $\left(\mathrm{N}: 12,10 \mathrm{~S}_{\mathrm{b}} / \mathrm{m}\right), \mu \mathrm{g} \mathrm{L}^{-1}$ & 47 \\
\hline Wavelength $\left(\lambda_{\max }\right), \mathrm{nm}$ & 520 \\
\hline Molar absorptivity $\mathrm{L} \mathrm{mol}^{-1} \mathrm{~cm}^{-1}$ & $1.04 \times 10^{5}$ \\
\hline $\mathrm{BSS} \%$ (N:5; 0.2 ve $3.0 \mu \mathrm{g} \mathrm{mL}^{-1}$ için) & 3.8 ve 2.3 \\
\hline
\end{tabular}

Table 1. Analytical properties of the proposed kinetic spectrophotometric method.

${ }^{\text {at }}$ is the minimum concentration that corresponds to the absorbance change (dA) of 0.001 in the optimum operating conditions of the device. 


\section{KARTAL TEMEL, GURKAN}

\subsection{The matrix effect}

In this study, in order to show the selectivity of the method, the effect of possible interfering anionic and cationic species on the quantitative analysis of Fe (II) $\left(0.1 \mathrm{mg} \mathrm{L}^{-1}\right)$ was tested. The results obtained in this investigation were summarized in Table 2. It is clear that interfering species, which can potentially be found in surface water and pharmaceutical samples with tolerance ratio ranging from 0.3 to 500 , did not exhibit a matrix effect in determination of $0.1 \mathrm{mg} \mathrm{L}^{-1}$ of $\mathrm{Fe}$ (II) by this kinetic approach. Therefore, it can be concluded that the developed method is fairly selective. In a narrow tolerance limit, possible interference of some species can be improved at significant tolerance ratios by using suitable selective masking agents for each interfering species, as can be seen in Table 2.

Table 2. Tolerance levels of foreign ions in the determination of $0.1 \mu \mathrm{g} \mathrm{mL}^{-1}$ of Fe (II).

\begin{tabular}{|c|c|}
\hline İnterfering species & $\begin{array}{l}\text { Tolerence level, } \\
\mu \mathrm{g} \mathrm{mL}^{-1}\end{array}$ \\
\hline $\begin{array}{l}\text { Acetic acid, tartaric acid, lactic acid, } \mathrm{HCO}_{3}^{-},{ }^{*} \mathrm{H}_{2} \mathrm{PO}_{4}^{-}, \mathrm{NO}_{3}^{-}, \mathrm{SO}_{4}^{-2}, \mathrm{Na}^{+}, \mathrm{K}^{+} \text {, } \\
\mathrm{NH}_{4}^{+}, \mathrm{Al}^{3+}, \mathrm{Zn}^{2+}, \mathrm{Ca}^{2+}, \mathrm{Cd}^{2+}, \mathrm{Ce}^{3+} \text { and } \mathrm{Sr}^{2+}\end{array}$ & $>500$ \\
\hline $\begin{array}{l}\text { Hydrazine sulfate, triethanolamine, formaldehyde, citric acid, sulfamic acid, } \\
\mathrm{As}^{3+}, \mathrm{Sb}^{3+}, \mathrm{Be}^{2+}, \mathrm{Ni}^{2+}, \mathrm{Co}^{2+}, \mathrm{La}^{3+}, \mathrm{Li}^{+}, \mathrm{Mg}^{2+}, \mathrm{Mn}^{2+}, \mathrm{Pb}^{2+}, \mathrm{Tl}^{+} \text {and } \mathrm{Bi}^{3+}\end{array}$ & $125-350$ \\
\hline $\mathrm{Cl}^{-}, \mathrm{F}^{-}$, hydroxyl amine hydrochloride, Tiron, $\mathrm{Cu}^{2+}$ and $\mathrm{Hg}^{2+}$ & $40-120$ \\
\hline$* \mathrm{~N}_{3}{ }^{-}, \mathrm{Ag}^{+}, \mathrm{Cr}^{3+}, \mathrm{Ce}^{4+}, * \mathrm{Mn}^{7+}, *$ EDTA, $*$ thiourea, $*$ EDTA, $* \mathrm{SCN}^{-}, \mathrm{Fe}^{3+}$ and $\mathrm{Sn}^{2+}$ & $5-35$ \\
\hline *Oxalate, $* \mathrm{Br}^{-}, * \mathrm{I}^{-}, * \mathrm{SO}_{3}{ }^{2-}, * \mathrm{~S}_{2} \mathrm{O}_{5}{ }^{2-}, \mathrm{W}^{6+}, \mathrm{Au}^{3+}, \mathrm{Pd}^{2+}$ and $\mathrm{Sn}^{4+}$ & $2-30$ \\
\hline${ }^{\mathrm{a}} \mathrm{NO}_{2}^{-},{ }^{\mathrm{b}} \mathrm{Cr}^{6+},{ }^{\mathrm{c}} \mathrm{V}^{4+},{ }^{\mathrm{c}} \mathrm{V}^{5+}$ and ${ }^{\mathrm{d}} \mathrm{Mo}^{6+}$ & $\begin{array}{l}0.3-1 \quad\left(25^{\mathrm{a}}, \quad 35^{\mathrm{b}}\right. \\
\left.>50^{\mathrm{c}}, 75^{\mathrm{d}}\right)\end{array}$ \\
\hline${ }^{\mathrm{e}} \mathrm{Zr}^{4+}$ and $^{\mathrm{e}} \mathrm{Ti}^{4+}$ & $0.1-0.3\left(>50^{\mathrm{d}}\right)$ \\
\hline
\end{tabular}

${ }^{\mathrm{a} A f t e r}$ pretreatment with $0.2 \mathrm{mlLof} 100 \mu \mathrm{g} \mathrm{mL}^{-1}$ sulfamic acid

${ }^{\mathrm{b}}$ After reduction with $0.2 \mathrm{~mL}$ of $100 \mu \mathrm{g} \mathrm{mL} \mathrm{m}^{-1} \mathrm{NH}_{2} \mathrm{OH} . \mathrm{HCl}$

${ }^{c}$ After masking with $0.1-0.3 \mathrm{~mL}$ of $100 \mu \mathrm{g} \mathrm{mL} \mathrm{L}^{-1}$ citric acid

${ }^{\mathrm{d}}$ After masking with $0.05-0.1 \mathrm{~mL}$ of $50 \mu \mathrm{g} \mathrm{mL}^{-1}$ trieathnolamine

${ }^{\mathrm{e}}$ After masking with $1.0 \mathrm{~mL}$ of $50 \mu \mathrm{g} \mathrm{mL}-1 \mathrm{NaF}$

*Ions producing negative interferences either byforming a stable complex with $\mathrm{Fe}$ (II) ions or reducing indicatior dye, $\mathrm{CBB}^{+}$

\subsection{Speciation analysis of iron}

In order to determine Fe (III) from difference between total $\mathrm{Fe}$ and $\mathrm{Fe}$ (II) amounts, it was reduced to $\mathrm{Fe}$ (II) and was subsequently complexed with 1,10-phen before kinetic analysis. Sulfite was selected as the reducing agent and its concentration for quantitative reduction of Fe (III) to Fe (II) was optimized by extracting $5 \mathrm{~mL}$ of $\mathrm{Fe}$ (III) at a concentration of $100 \mu \mathrm{g} \mathrm{L}^{-1}$ in the presence of varying amounts of sulfite $\left(0.02-0.2 \mathrm{~mol} \mathrm{~L}^{-1}\right)$ for $15 \mathrm{~min}$ at $40^{\circ} \mathrm{C}$ in ultrasonic bath $(350 \mathrm{Watt}, 40 \mathrm{kHz})$. The results showed that $\mathrm{Fe}$ (III) could be quantitatively reduced when the sulfite concentration was $0.12 \mathrm{~mol} \mathrm{~L}^{-1}$. Furthermore, the capability of the method for speciation analysis of iron was investigated by processing synthetic model solutions of $\mathrm{Fe}$ (III) and Fe (II) according to the given kinetic procedure. The results in Table 3 reveal that the recovery of both species of iron is quantitative; thus the analytical system is capable of speciation of iron. 
Table 3. Recovery of Fe (II) and Fe (III) ions from $8 \mathrm{~mL}$ of model aqueous solutions at $\mathrm{pH} 4.0$.

\begin{tabular}{llllll}
\hline \multicolumn{2}{l}{ Added, $\mu \mathrm{g} \mathrm{L}^{-1}$} & \multicolumn{3}{l}{ Found, $\mu \mathrm{g} \mathrm{L}^{-1}$} & ${ }^{\mathrm{a}}$ Recovery \% \\
\hline $\mathrm{Fe}(\mathrm{II})$ & $\mathrm{Fe}(\mathrm{III})$ & $\mathrm{Fe}(\mathrm{II})$ & $\mathrm{Fe}(\mathrm{III})$ & $\mathrm{Fe}(\mathrm{II})$ & $\mathrm{Fe}(\mathrm{III})$ \\
100 & 0 & $101.5 \pm 3.0$ & - & 101.5 & - \\
75 & 25 & $73.5 \pm 3.0$ & $24.0 \pm 3.0$ & 98.0 & 96.0 \\
25 & 75 & $24.5 \pm 4.0$ & $76.5 \pm 4.0$ & 98.0 & 102.0 \\
50 & 50 & $48.5 \pm 3.0$ & $48.0 \pm 3.0$ & 97.0 & 96.0 \\
0 & 100 & - & $96.5 \pm 4.0$ & - & 96.5 \\
\hline
\end{tabular}

${ }^{a}$ The mean and standard deviation of three measurements

\subsection{The analytical applications of the method}

At initial, the method accuracy was validated by analysis of a certified reference material (CRM); CRM1643 e simulated fresh water-trace elements supplied from NIST as well as recovery studies from spiked samples. Clearly, it has been observed that the result found by the present kinetic method is statistically in agreement with the certified value. Moreover, the recovery rates were highly quantitative in range of $99.7-100.8 \%$. The analytical applicability of the proposed method was checked by the quantitation of $\mathrm{Fe}$ (II) in pharmaceutical and some environmental water samples. The analysis was also performed as total $\mathrm{Fe}$ using three pointed standard addition method around the method determination limit after prereduction of $\mathrm{Fe}$ (III) to $\mathrm{Fe}$ (II) with sulfite at $\mathrm{pH} 4.0$ in ultrasonic bath. In terms of method validation, it can be seen from Table 4(b and c) that the results found by the method are highly compatible with the real Fe (II) contents of the certificated pharmaceutical samples. Also, the recovery studies from spiked samples for different concentration levels in range of $0.2-2.0 \mathrm{mg} \mathrm{L}^{-1}$ were conducted. It was found that the recovery rates were quantitative with recoveries ranging from $96.7 \%$ to $105 \%$ for pharmaceutical samples and ranging from $92 \%$ to $99 \%$ for Fe (II) and total Fe in environmental waters such as well, river and lake waters. 


\section{KARTAL TEMEL, GURKAN}

Table 4(a) The analysis results of certified water samples by means of the proposed kinetic method

\begin{tabular}{|c|c|c|c|c|c|c|c|c|c|c|c|}
\hline \multirow[t]{2}{*}{$\begin{array}{l}\text { Certified environmenta } \\
\text { sample }\end{array}$} & \multirow[t]{2}{*}{ water } & \multicolumn{2}{|c|}{$\begin{array}{l}\text { Certified value, } \mu \mathrm{g} \\
\mathrm{L}^{-1}\end{array}$} & \multicolumn{2}{|c|}{ Added, $\mu \mathrm{g} \mathrm{L^{-1 }}$} & & \multicolumn{2}{|c|}{ *Found, $\mu \mathrm{g} \mathrm{L} \mathrm{L}^{-1}$} & \multicolumn{2}{|c|}{ Recovery\% } & \multirow[t]{2}{*}{$\begin{array}{l}* * * \text { The statistical } \mathrm{t} \text { - } \\
\text { and } \mathrm{F} \text {-values }\end{array}$} \\
\hline & & $\mathrm{Fe}(\mathrm{II})$ & $\mathrm{Fe}(\mathrm{III})$ & $\mathrm{Fe}(\mathrm{II})$ & $\mathrm{Fe}(\mathrm{III})$ & $* * \mathrm{Fe}(\mathrm{II})$ & Total Fe & $\mathrm{Fe}(\mathrm{III})$ & $\mathrm{Fe}(\mathrm{II})$ & $\mathrm{Fe}(\mathrm{III})$ & \\
\hline \multirow{4}{*}{$\begin{array}{l}\text { NIST-1643e Simulated } \\
\text { water-Trace elements }\end{array}$} & fresh & $19.62 \pm 0.6$ & - & - & - & $19.70 \pm 0.18$ & - & - & - & - & $0.275(0.852)$ \\
\hline & & & & 5 & 15 & $24.65 \pm 0.28$ & $39.75 \pm 0.34$ & 15.10 & 99.0 & 100.7 & \\
\hline & & & & 15 & 5 & $34.70 \pm 0.32$ & $39.74 \pm 0.36$ & 5.04 & 100.5 & 100.8 & \\
\hline & & & & 10 & 10 & $29.80 \pm 0.30$ & $39.77 \pm 0.35$ & 9.97 & 101.0 & 99.7 & \\
\hline
\end{tabular}

*The mean value plus its standard deviation of five replicate measurements at $95 \%$ confidence level

**The results found by subtracting the amount of $\mathrm{Fe}(\mathrm{II})$ from those of total $\mathrm{Fe}$ before and after reducing with $1.25 \mathrm{~mL}$ of $0.01 \mathrm{moL} \mathrm{L}-1$ sulfite with time of 5 min at $40^{\circ} \mathrm{C}$ and $\mathrm{pH} 4.5$ formate buffer

***The statistical t- and F-values for 95\% confidence level and degree of freedom, 4 are 2.78 and 5.63 respectivel 
Cumhuriyet Üniversitesi Fen Fakültesi Fen Bilimleri Dergisi (CFD), Cilt 38, No. 2 (2017) ISSN: 1300-1949
Cumhuriyet University Faculty of Science Science Journal (CSJ), Vol. 38, No. 2 (2017) ISSN: $1300-1949$

http://dx.doi.org/10.17776/cumuscij.302489

Table 4(b). Analysis of pharmaceutical products by the proposed kinetic method.

\begin{tabular}{|c|c|c|c|c|c|c|c|c|c|c|}
\hline \multirow[t]{2}{*}{ Sample } & \multirow{2}{*}{$\begin{array}{l}\text { Certified } \\
\text { value, } \\
\text { mg L L }^{-1}\end{array}$} & \multicolumn{2}{|c|}{$\mathrm{Fe}(\mathrm{II}), \mathrm{mg} \mathrm{L}^{-1}$} & \multicolumn{2}{|c|}{$\mathrm{Fe}(\mathrm{III}), \mathrm{mg} \mathrm{L}^{-1}$} & \multirow{2}{*}{$\begin{array}{c}\text { Total Fe, } \\
\mathrm{mg} \mathrm{L}^{-1}\end{array}$} & \multicolumn{2}{|c|}{ Recovery\% } & \multicolumn{2}{|c|}{ RSD \% } \\
\hline & & Added & Found & Added & Found & & $\mathrm{Fe}(\mathrm{II})$ & $\mathrm{Fe}(\mathrm{III})$ & $\mathrm{Fe}(\mathrm{II})$ & $\begin{array}{c}\text { Total } \\
\mathrm{Fe}\end{array}$ \\
\hline \multirow{3}{*}{$\begin{array}{l}\text { Gynoferon } \\
\text { draje }\end{array}$} & \multirow{3}{*}{0.8} & - & $0.785 \pm 0.03$ & & 0.00 & & 98.13 & & 3.82 & - \\
\hline & & 0.5 & $1.282 \pm 0.04$ & 2.00 & 2.005 & $3.287 \pm 0.11$ & 99.4 & 100.25 & 3.12 & 3.35 \\
\hline & & 1.0 & $1.789 \pm 0.05$ & 3.00 & 2.995 & 4.78 & 100.4 & 99.83 & 2.79 & 2.51 \\
\hline \multirow{3}{*}{$\begin{array}{l}\text { Ferrosanol } \\
\text { oral drop }\end{array}$} & \multirow{3}{*}{1.2} & 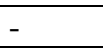 & $1.16 \pm 0.04$ & & 0.00 & & 96.7 & - & 3.45 & \\
\hline & & 0.2 & $1.37 \pm 0.04$ & 2.00 & 2.02 & $3.39 \pm 0.10$ & 105.0 & 101.0 & 2.92 & 2.95 \\
\hline & & 2.0 & $3.15 \pm 0.10$ & 1.00 & 0.97 & $4.18 \pm 0.13$ & 99.5 & 103.0 & 3.17 & 3.11 \\
\hline \multirow{3}{*}{$\begin{array}{l}\text { Maltofer } \\
\text { oral } \\
\text { solution }\end{array}$} & \multirow{3}{*}{0.8} & & $0.803 \pm 0.03$ & & 0.00 & & 100.4 & & 3.73 & \\
\hline & & 0.2 & $1.27 \pm 0.04$ & 0.40 & 0.38 & 1.68 & 105.0 & 105.0 & 3.15 & 2.98 \\
\hline & & 0.8 & $1.85 \pm 0.05$ & 3.00 & 3.04 & $4.93 \pm 0.12$ & 98.7 & 102.3 & 2.70 & 2.43 \\
\hline
\end{tabular}

Table 4(c.) Speciative analysis of Fe (II), Fe (III) and total Fe in environmental waters by catalytic kinetic method

\begin{tabular}{cccccccc}
\hline \multirow{2}{*}{ Samples } & \multicolumn{2}{c}{ Added $\left(\mu \mathrm{g} \mathrm{L}^{-1}\right)$} & \multicolumn{2}{c}{ Found by catalytic kinetic method $\left(\mu \mathrm{g} \mathrm{L}^{-1}\right)^{*}$} & \multicolumn{2}{c}{ Recovery \% } \\
\cline { 2 - 8 } Well water & $\mathrm{Fe}(\mathrm{II})$ & $\mathrm{Fe}(\mathrm{III})$ & $\mathrm{Fe}(\mathrm{II})$ & Total Fe & $\mathrm{Fe}(\mathrm{III}) * *$ & $\mathrm{Fe}(\mathrm{II})$ & Total Fe \\
& - & - & $21.6 \pm 0.5$ & $32.4 \pm 0.8$ & 10.8 & - & - \\
& 10 & 5 & $31.0 \pm 0.8$ & $47.2 \pm 1.3$ & 16.2 & 94 & 99 \\
\hline Tap water & - & - & $14.5 \pm 0.3$ & $18.7 \pm 0.4$ & 4.2 & - & - \\
& 5 & 15 & $19.1 \pm 0.4$ & $38.5 \pm 1.2$ & 19.4 & 92 & 97 \\
& 15 & 5 & $29.0 \pm 0.7$ & $38.3 \pm 1.2$ & 9.3 & 97 & 99 \\
\hline River water & - & - & $15.2 \pm 0.3$ & $32.5 \pm 0.8$ & 17.3 & - & - \\
& 5 & 10 & $19.7 \pm 0.4$ & $47.1 \pm 1.3$ & 27.8 & 90 & 97 \\
& 10 & 5 & $24.8 \pm 0.5$ & $47.2 \pm 1.3$ & 22.7 & 96 & 98 \\
\hline Lake water & - & - & $16.6 \pm 0.3$ & $42.5 \pm 1.2$ & 25.9 & - & - \\
& 5 & 10 & $21.3 \pm 0.5$ & $57.1 \pm 1.5$ & 30.3 & 94 & 97 \\
& 10 & 5 & $26.1 \pm 0.6$ & $57.2 \pm 1.5$ & 25.3 & 95 & 98 \\
\hline
\end{tabular}

*The mean value and its standard deviation of five replicate measurements at $95 \%$ confidence level.

**The results found by subtracting the amount of $\mathrm{Fe}$ (II) from those of total $\mathrm{Fe}$ after pe-reducing with sodium sulfite at $\mathrm{pH}$ 4.0 .

***The chemical properties of lake water samples (Hafik, Sivas, Turkey). The mean analysis values obtained by means of thirty replicate measurements: $\mathrm{pH}$ : 7.45, total hardness (FS $\left.{ }^{\circ}\right) 17.66$, total alkalinity $134.67 \mathrm{mg} \mathrm{L}^{-1}$, Ca $58.40 \mathrm{mg} \mathrm{L}^{-1}$, $\mathrm{Mg}_{6.66}$ $\mathrm{mg} \mathrm{L}^{-1}, \mathrm{Cl}^{-} 34.10 \mathrm{mg} \mathrm{L}^{-1}, \mathrm{HCO}_{3}^{-} 134.55 \mathrm{mg} \mathrm{L}^{-1}$

\footnotetext{
* Corresponding author. Email address: nkartal@ cumhuriyet.edu.tr 


\section{KARTAL TEMEL, GURKAN}

\subsection{Comparison to other reported kinetic methods}

A comparison of the presented method with some other reported spectrophotometric determination of iron as Fe (II) determination some samples is given in Table 5. Apparently, the presented method has low LOD (14.1 $\left.\mu \mathrm{g} \mathrm{L}^{-1}\right)$, wide linear range $\left(0.05-1.0\right.$ ve $\left.0.25-5.0 \mu \mathrm{g} \mathrm{mL}^{-1}\right)$, minimum solvent consumption, quantitative recovery $(98.7-102.7 \%)$.

Table 5. Some spectrophotometric methods reported in the literature for the catalytic-kinetic determination of iron in selected samples.

\begin{tabular}{lccc}
\hline Reagent & $\begin{array}{c}\text { Linear working } \\
\text { range, } \mu \mathrm{g} \mathrm{L}^{-1}\end{array}$ & $\begin{array}{c}\text { Detection limit } \\
\mu \mathrm{g} \mathrm{L}^{-1}\end{array}$ & References \\
\hline$N$-phenylanthranilic acid & $2-500$ & 0.88 & {$[31]$} \\
m-Acetylchlorophosphonazo & $0-100$ & 1.34 & {$[32]$} \\
$p$-acetylarsenazo & $0.10-4.0$ & 0.031 & {$[33]$} \\
Diphenylamine & $1-100$ & 0.52 & {$[34]$} \\
2,3-Dichloro-6-(3-carboxy-2- & $1.0-20$ & 280 & {$[35]$} \\
hydroxy-1-naphthylazo)quinoxaline & & & \\
Coomassie Brillant Blue 2R & $50-1000$ and 250- & 14.1 & This study \\
& 5000 & & \\
\hline
\end{tabular}

\section{CONCLUSIONS}

The results presented clearly demonstrate that catalytic effect of $\mathrm{Fe}$ (II) in the presence of 1,10-phen as activator on the oxidation of $\mathrm{CBB}^{+}$by bromate can be used for the determination of trace amounts of $\mathrm{Fe}$ (II) at pH 2.0. The proposed kinetic method was found to be accurate, reproductive, sensitive, and selective for only Fe (II) without interference of $\mathrm{Fe}$ (III). Also the short time required method is easy to operate, simple, fast, and can be performed with available and cheaper chemicals. Therefore, the proposed method could be applied for pharmaceutical and environmental analyses with satisfactory results.

\section{REFERENCES}

[1]. J.D. Lee, Concise Inorganic Chemistry, 4rd ed., Chapman \& Hall, 1991.

[2]. H.R. Pouretedal, M.H. Keshavars, G.Vanony, Asian J. Chem., 2007, 4969-4976.

[3]. D.L. Tsalev, Manganese. In: Tsalev DL, editor. Atomic absorption spectrometry in occupational and environmental health practice. Vol. II. Determination of individual elements. Boca Raton, FL: CRC Press, Inc; 1983.

[4]. J.H. Martin, R.M. Gordon, S.E. Fitzwater, W.W. Broenkow, Deep-Sea Res., 1989, 36, 1793-1802.

[5]. D. Nicholls, The Chemistry of Iron, Cobalt and Nickel, Pergamon Press, 1973, 979-989.

[6]. B. Jankiewicz, B, Ptaszynski, A. Turek, Pol. J.Environ.Stud., 2002, 11, 745-749.

[7]. J.R. Dojlido, G.A. Best, Pren. Hall Inc. Englewood, 1993, 21, 251.

[8]. S. Lunvongsa, M. Oshima, S. Motomizu, Talanta, 2006, 68, 969-973.

[9]. K. Hirayama, N. Unohara, Anal. Chem., 1988, 60, 2573-2580.

[10]. T. N. Kiran Kumar, H. D. Revanasiddappa, Anal. Bioanal. Chem., 2003, 376, 1126-1130.

[11]. K.S. Patel, A. Shukla, A. Goswami, S.K. Chandavanshi, P. Hoffmann, Fresenius J. Anal. Chem., 2001, 369, 530-534.

[12]. M.A. Akl, Microchem. J., 2003, 75, 199-209. 


\section{Determination of Trace Amounts of Total Fe as Fe (II)}

[13]. C.D. Stalikas, A.Ch. Pappas, M. I. Karayannis, P.G. Veltsistas, Microchim. Acta, 2003, 142, 43-48.

[14]. Z. Zeng, R.A. Jewsbury, Analyst, 2000, 125, 1661-1665.

[15]. K. Saitoh, T. Hasebe, N. Teshima, M. Kurihara, T.Kawashima, Anal. Chim. Acta, 1998, 376, $247-254$.

[16]. S. Lunvongsa, M. Oshima, S. Motomizu, Talanta, 2006, 68, 969-973.

[17]. A. Tsuji, N. Teshima, M. Kurihara, S. Nakano, T. Kawashima, Talanta, 200,52, 161-167.

[18]. J. Zarebski, Fresenius J. Anal. Chem. 1996, 356, 299-302.

[19]. W. Qin, Z.J. Zhang, F.C. Wang, Fresenius J. Anal. Chem. 1998, 360, 130-132.

[20]. S. Pozdniskova, A. Padaruskas, Analyst, 1998, 123, 1497-1500.

[21]. V. Lazic, R. Fantoni, F. Colao, A. Santagata, A. Morone, V. Spizzichino, J. Anal. Atom. Spectrom., 2004, 19, 429-436.

[22]. P.S. Roldan, I.L. Alcantara, C.C.F. Padilha, Fuel, 2005, 84, 305-309.

[23]. S. Osznadowski, A. Pikus, Talanta, 2002, 58, 773.

[24]. P.R. Bontchev, Talanta, 1970, 17, 499.

[25]. T.S. Lee, I.M. Kolthoff, D.L. Leussing, J. Am. Chem. Soc., 1948, 70, 2348-2352.

[26]. J.E. Dickens, F. Basolo, H.M. Neumann, J. Am. Chem. Soc., 1957, 79, 1286-1290.

[27]. D.W. Margerum, J. Am. Chem. Soc., 1957, 79, 2728-2733.

[28]. B.R. James, J.R. Lyons, R.J.P. Williams, Biochemistry. 1962, 1, 379-385.

[29]. G. Nord, B. Pedersen, E. Bjergbakke, J. Am. Chem. Soc., 1983, 105, 1913-1919.

[30]. N.Demirhan, F.T. Elmal1, Turk. J. Chem, 2003, 27, 315-321.

[31]. A.M. Stoyanova, Anal. Sci., 2008, 24.

[32]. Q.Z. Zhai, L.X. Jin, Instrum. Sci. Technol., 2009, 37, 462-471.

[33]. Q.Z. Zhai, Bull. Chem. Soc. Ethiop., 2009, 23, 445-450.

[34]. A. Stoyanova, J. Univ. Chem. Technol. Metall., 2006, 41, 205-210.

[35]. A.S. Amin, A.A. Gouda, Talanta, 2008, 76, 1241-1245. 